\title{
A cross-sectional single-centre study on the spectrum of Pompe disease, German patients: molecular analysis of the GAA gene, manifestation and genotype-phenotype correlations
}

Andreas Herzog ${ }^{1}$, Ralf Hartung ${ }^{1}$, Arnold J J Reuser ${ }^{2}$, Pia Hermanns ${ }^{1}$, Heiko Runz ${ }^{3}$, Nesrin Karabul', Seyfullah Gökce ${ }^{1}$, Joachim Pohlenz ${ }^{1}$, Christoph Kampmann ${ }^{1}$, Christina Lampe ${ }^{1}$, Michael Beck ${ }^{1}$ and Eugen Mengel ${ }^{1^{*}}$

\begin{abstract}
Background: Pompe disease (Glycogen storage disease type II, GSD II, acid alpha-glucosidase deficiency, acid maltase deficiency, OMIM \# 232300) is an autosomal-recessive lysosomal storage disorder due to a deficiency of acid alpha-glucosidase (GAA, acid maltase, EC 3.2.1.20, Swiss-Prot P10253). Clinical manifestations are dominated by progressive weakness of skeletal muscle throughout the clinical spectrum. In addition, the classic infantile form is characterised by hypertrophic cardiomyopathy.

Methods: In a cross-sectional single-centre study we clinically assessed 3 patients with classic infantile Pompe disease and 39 patients with non-classic presentations, measured their acid alpha-glucosidase activities and analysed their GAA genes.

Results: Classic infantile patients had nearly absent residual enzyme activities and a typical clinical course with hypertrophic cardiomyopathy until the beginning of therapy. The disease manifestations in non-classic patients were heterogeneous. There was a broad variability in the decline of locomotive and respiratory function. The age of onset ranged from birth to late adulthood and correlated with enzyme activities. Molecular analysis revealed as many as 33 different mutations, 14 of which are novel. All classic infantile patients had two severe mutations. The most common mutation in the non-classic group was c.-32-13T>G. It was associated with a milder course in this subgroup.

Conclusions: Disease manifestation strongly correlates with the nature of the GAA mutations, while the variable progression in non-classic Pompe disease is likely to be explained by yet unknown modifying factors. This study provides the first comprehensive dataset on the clinical course and the mutational spectrum of Pompe disease in Germany.
\end{abstract}

Keywords: Glycogen storage disease type II, Pompe disease, GAA, Lysosomal storage diseases, Genotype phenotype correlations, Enzyme replacement therapy

\footnotetext{
* Correspondence: eugen.mengel@unimedizin-mainz.de

${ }^{1}$ Center for Pediatric and Adolescent Medicine, University Medical Center, Langenbeckstraße 1, 55131, Mainz, Germany

Full list of author information is available at the end of the article
} 


\section{Background}

Pompe disease (Glycogen storage disease type II, GSD II, acid alpha-glucosidase deficiency, acid maltase deficiency, OMIM \# 232300) is an autosomal-recessive lysosomal storage disorder caused by a deficiency of acid alpha-glucosidase (GAA, acid maltase, EC 3.2.1.20, SwissProt P10253) [1]. Accumulation of glycogen in various tissues leads to a broad and continuous spectrum of clinical phenotypes that can be categorised according to clinical features into classic infantile and non-classic forms. Patients with non-classic disease can further be divided over those with a childhood, juvenile or adult course [1]. All patients show progressive skeletal muscle weakness which results in a decline of locomotive and respiratory functions. In addition, the classic infantile form is characterised by hypertrophic cardiomyopathy [1]. Classic infantile patients show first symptoms within the first months of life with heart failure and a profound muscle weakness. Without therapy, most of classic infantile patients die within the first year of life $[2,3]$.

Among patients with non-classic forms complaints may begin at any time between early childhood and late adulthood $[4,5]$. With disease progression patients develop progressive myopathy that may result in immobilisation and respiratory insufficiency [4].

The frequency of Pompe disease varies among different ethnic groups and is estimated as $1 / 138,000$ for classic infantile and 1/57,000 for non-classic patients in the Netherlands [1].

The GAA gene (OMIM \# 606800) is located on chromosome 17q25.2-q25.3 [6]. With a length of $\sim 20 \mathrm{~kb}$ it contains 20 exons and encodes for a cDNA of $3.6 \mathrm{~kb}$, the start codon beginning at position 33 of exon 2 [7]. The resulting product is a protein of 952 amino acids [8].

Until now, 361 variants have been described in the GAA gene, 78 of which are polymorphisms while 248 are considered as disease-causing mutations [9]. Mutations are randomly spread over the whole gene and typically private. However, some mutations appear with considerable frequency in distinct ethnic groups. For instance, in cohorts of non-classic Caucasian patients c.-32-13 $\mathrm{T}>\mathrm{G}$ is the most common mutation with a frequency of $34-47 \%$ [10-14]. This mutation leads to impaired splicing of exon 2 with about $10 \%$ of normally spliced products [15].

The clinical course of Pompe disease primarily depends on the residual acid alpha-glucosidase activity as determined by the genotype $[10,16,17]$. However, this correlation is afflicted with a broad variability in enzyme activities as well as in clinical signs, particularly in patients with the non-classic forms [18].

Here we describe disease presentation, enzymatic and molecular findings in a German cohort consisting of 3 patients with classic infantile Pompe disease and 39 patients with non-classic disease presentation.

\section{Materials and methods \\ Patients and clinical data}

Forty-two patients with a clinical and enzymatic diagnosis of Pompe disease were included in this study.

Patients are usually categorised with respect to age of onset, extent of organ involvement and disease progression [1]. We distinguished patients with a classic infantile course that are severely affected by hypertrophic cardiomyopathy, onset in the first month of life and rapid progression from those with a non-classic course with predominant muscle involvement but without hypertrophic cardiomyopathy. Non-classic disease includes the childhood, juvenile and adult forms, which are not unambiguously distinguished in the literature. We therefore defined the childhood forms by having motor delay and progression of muscle weakness before achievement of motor milestones. The juvenile forms were defined by progression of muscle weakness after achievement of motor milestones but before the end of growth. Adult forms were defined by having a progression of muscle weakness not until the end of growth. It is of note that non-classic patients may have an earlier onset followed by temporary regression of symptoms before muscle weakness becomes progressive.

In non-classic patients all data were collected in the observation period before starting enzyme replacement therapy, when they only received supportive care. Since we initiated enzyme replacement therapy with alglucosidase alpha in all classic infantile patients shortly after referring to our centre, data on their natural course are limited and amended by a description of the course under ERT.

Clinical data were retrospectively collected from health records. Assessment included physical examination, manual muscle testing using the Medical Research Council (MRC) grading scale for different muscle groups, the Walton \& Gardner-Medwin scale, and the per cent predicted forced vital capacity (FVC) in sitting and supine position. A total MRC-score was defined as the mean of MRC-grades of neck flexion, shoulder abduction, elbow flexion, hip flexion, knee extension and foot extension. Echocardiography was performed as previously described [19].

Patient 42 suffers from a 2q37 deletion syndrome in addition to Pompe disease (unpublished). Since it cannot be excluded that muscular hypotonia in this patient is caused by genetic factors other than pathogenic variants in the GAA gene this patient was excluded from clinical characterisation [20].

Since parents of patients 2 and 3 are consanguineous, there are four independent alleles in classic infantile and 73 independent alleles in non-classic patients. 
All patients were Caucasians, patients 2 and 3 having a Turkish, the others having a German ancestry.

\section{Biochemical assays}

In 32 of the 42 patients GAA activity was measured in isolated lymphocytes of fresh blood samples with 4-methylumbelliferyl- $\alpha$-D-glucopyranoside as substrate and acarbose as an inhibitor of interfering maltase-glucoamylase activity according to a standardised protocol [21,22]. The GAA activity was expressed in nmol hydrolysed 4-MU$\alpha \mathrm{Glc} /$ hour/mg protein (nmole/mg/hr). In 7 patients GAA activity was measured according to a former protocol in isolated lymphocytes with 4-methylumbelliferyl- $\alpha-\mathrm{D}$ glucopyranoside as substrate without acarbose and in 3 patients enzyme activities were measured in external laboratories. Those enzyme activities were not included in further analysis.

\section{Mutation analysis}

Direct sequencing of the GAA gene was performed using standard procedures (Additional file 1). Exons of the gDNA were amplified using long range PCRs of eight fragments of the GAA gene. PCR of cDNA was performed in overlapping fragments as described previously [23]. To be able to detect or exclude large deletions that escape routine Sanger sequencing long range PCRs over more fragments were carried out.

Obtained sequences were compared with the reference sequences NM_000152.3 and NC_000017.9. The A of the start codon, defining position +1 of $\mathrm{cDNA}$, lies at positions 3032 and 368 of those sequences, respectively. The ATG codon represents +1 of the amino acid numbering according to NP_00143.2. Variants were described according to the guidelines of the Human Genome Variation Society [24]. All nucleotide differences between the patients and the reference sequence were compared to the GAA mutation database of the Erasmus MC University Medical Center Rotterdam and to the dbSNP database of the National Center of Biological Information $[9,25]$. Variants that were listed as polymorphisms or assured disease causing mutations in the GAA mutation database were not further characterised. Novel nonsense mutations as well as frameshift mutations leading to a premature stop codon were assumed to be disease causing if the stop codon was lying upstream of another known disease causing nonsense mutation. All other mutations were classified as potentially disease causing and were further analysed.

The pathogenic nature of novel missense mutations was verified by restriction digestion or direct sequencing of 120 alleles of unaffected individuals. Furthermore an alignment with orthologous sequences was performed.

To identify transcriptional products of splice site mutations, PCR products were cloned into an expression vector system. We purified cDNAs using the peqGOLD MicroSpin Gel Extraction Kit (Peqlab, Erlangen, Germany) and cloned them into the $\mathrm{pGEM}^{\circledR}-\mathrm{T}$ vector (Promega, Mannheim, Germany). After transformation into XL10Gold $^{\circledR}$ Ultracompetent Cells (Stratagene, Waldbronn, Germany) positive clones were selected and plasmid DNA isolated using the Zyppy ${ }^{\text {тm }}$ Plasmid Miniprep Kit (Zymo research, Freiburg, Germany).

\section{Statistical analysis}

Descriptive statistical analysis was performed using SPSS Statistics version 17.0 (SPSS Software, München, Germany). Since clinical data were not comprehensive in all patients, analysis was done with list-wise deletion of missing values.

\section{Ethics}

This study was approved in the context of the Pompe Registry by the ethics committee of Landesärztekammer Mainz, Germany.

\section{Results}

\section{Disease manifestations in classic infantile patients}

Patient 1 was born after an inconspicuous pregnancy with Cesarean section in the $38^{\text {th }}$ week of gestation because of a silent cardiotocogram with a birth weight of $3.6 \mathrm{~kg}$ (Table 1, Table 2). Postpartum she had a respiratory distress syndrome that required brief ventilation with facemask. On day three after birth she had myocloni and a periodic breathing with reduced blood oxygen saturation. In further course she developed a progressive muscular hypotonia and dystonia with reduction of movements. Left ventricular hypertrophy was diagnosed at the age of 2.5 month. Diagnosis was made at the age of 3 month. At the start of enzyme replacement therapy at the age of 5 month, she had generalised muscular hypotonia as well as hypertrophic cardiomyopathy.

Patient 3 was born spontaneously in the $39^{\text {th }}$ week of gestation with a birth weight of $3.2 \mathrm{~kg}$ and developed initially normal. Aged 2 month she was weak in breathing and sucking. She developed generalised muscular hypotonia with respiratory insufficiency as well as hypertrophic cardiomyopathy.

The diagnostic delay in these two patients was 3 and 1 month, respectively.

The diagnosis in patient 2 was prenatally established and was based on the finding of hypertrophic cardiomyopathy. The prenatal development was otherwise normal and the baby boy was born spontaneously in the $37^{\text {th }}$ week of gestation with a birth weight of $3.1 \mathrm{~kg}$. Enzyme replacement therapy was started at the fourth day of life when the baby boy was still asymptomatic. The intervention resulted in a regression of cardiomyopathy 
Table 1 Clinical, enzymatic and molecular information on 42 German patients with Pompe disease

\begin{tabular}{lllllll}
\hline Patient & $\begin{array}{l}\text { Age at onset } \\
\text { [years] }\end{array}$ & First symptoms & $\begin{array}{l}\text { Walton \& Gardner- } \\
\text { Medwin scale }\end{array}$ & $\begin{array}{l}\text { FVC in } \\
\text { sitting/ supine } \\
\text { position [\%] }\end{array}$ & $\begin{array}{l}\text { GAA activity } \\
\text { [nmole/mg/hr] }\end{array}$ & $\begin{array}{l}\text { Allele } 1 \\
\text { Allele } 2\end{array}$ \\
\hline
\end{tabular}

[years]

\begin{tabular}{|c|c|c|c|c|c|c|c|c|c|}
\hline \multicolumn{10}{|c|}{ classic infantile } \\
\hline 1 & postnatal & respiratory insufficiency & - & - & $1.0^{5}$ & c. $1799 \mathrm{G}>\mathrm{A}$ & c. $2481+102 \_2646+31 \mathrm{del}$ & 6 & $f$ \\
\hline 2 & prenatal & cardiomegaly & - & - & $0.3^{5}$ & c. $1637-2 A>G$ & c.1637-2A>G & 2 & $m$ \\
\hline 3 & $3 / 12$ & $\begin{array}{l}\text { adynamia in breathing } \\
\text { and sucking }\end{array}$ & - & - & $1.2^{\xi}$ & $\begin{array}{l}\text { c.[2740dup; } \\
\text { 2742dup] }\end{array}$ & c.[2740dup; 2742dup] & $4 / 12$ & $f$ \\
\hline \multicolumn{10}{|c|}{ childhood } \\
\hline 4 & 1 & no standing aged 1 year & 3 & $48 / 50$ & $0.01^{\S}$ & c. $-32-13 T>G$ & c.1051delG & 9 & $\mathrm{~m}$ \\
\hline 5 & 1.5 & no free walking aged 1.5 years & $\begin{array}{l}8 \text { (walking support } \\
\text { aged } 15 \text { years, wheelchair } \\
\text { aged } 17 \text { years) }\end{array}$ & $?$ & $0.2^{\xi}$ & c. $2297 \mathrm{~A}>\mathrm{G}$ & c. $1561 G>A$ & 29 & $f$ \\
\hline 6 & 1.5 & no free walking aged 1.5 years & 3 & $32 / 27$ & $2.0^{5}$ & c. $1370 C>T$ & c.1128_1129delinsC & 4 & $\mathrm{~m}$ \\
\hline \multicolumn{10}{|c|}{ juvenile } \\
\hline 7 & $1 / 12$ & $\begin{array}{l}\text { adynamia in breathing } \\
\text { and swallowing }\end{array}$ & 0 & $75 / 78$ & $2.1^{\$}$ & c. $-32-13 T>G$ & c.2481+102_2646+31del & 14 & $\mathrm{~m}$ \\
\hline 8 & 0 & $\begin{array}{l}\text { muscular hypotonia, adynamia } \\
\text { in swallowing }\end{array}$ & $\begin{array}{l}7 \text { (wheelchair aged } \\
19 \text { years) }\end{array}$ & 32 & $\#$ & c. $-32-13 T>G$ & c.525delT & 21 & $f$ \\
\hline 9 & 1 & no standing aged 1 year & 2 & $72 / 54$ & $0.8^{5}$ & c. $-32-13 T>G$ & c. $2481+102 \_2646+31 \mathrm{del}$ & 30 & $\mathrm{~m}$ \\
\hline $10^{\gamma}$ & 1 & no crawling aged 1 year & 0 & $71 / 66$ & $0.5^{5}$ & c. $-32-13 \mathrm{~T}>\mathrm{G}$ & c.525delT & 15 & $\mathrm{~m}$ \\
\hline 11 & 1 & $\begin{array}{l}\text { muscle weakness, adynamia } \\
\text { in swallowing }\end{array}$ & 3 & $80 / 74$ & $1.2^{5}$ & c. $-32-13 \mathrm{~T}>\mathrm{G}$ & c. $1548 \mathrm{G}>\mathrm{A}$ & 20 & $f$ \\
\hline 12 & 2 & muscle weakness & 0 & 89/86 & $0.5^{\varsigma}$ & c. $-32-13 T>G$ & C. $118 \mathrm{C}>\mathrm{T}$ & 20 & $\mathrm{~m}$ \\
\hline 13 & 2 & muscle weakness & 2 & $?$ & $0.02^{\S}$ & c. $-32-13 T>G$ & c. $2214 \mathrm{G}>\mathrm{A}$ & 2 & $f$ \\
\hline 14 & 6.5 & muscle weakness & 0 & $91 / 94$ & $0.03^{\S}$ & c. $-32-13 \mathrm{~T}>\mathrm{G}$ & C.1561G >A & 5 & $\mathrm{~m}$ \\
\hline 15 & 3 & $\begin{array}{l}\text { developmental retardation, } \\
\text { abnormal gait }\end{array}$ & 2 & $28 / 20$ & $0.02^{\S}$ & c. $-32-13 \mathrm{~T}>\mathrm{G}$ & $c .2738 C>G$ & 20 & $\mathrm{~m}$ \\
\hline 16 & 13 & muscle weakness & 0 & $82 / 75$ & $0.9^{\$}$ & c. $-32-13 \mathrm{~T}>\mathrm{G}$ & c. $-32-13 \mathrm{~T}>\mathrm{G}$ & 13 & $\mathrm{~m}$ \\
\hline 17 & 9 & limb girdle weakness & $\begin{array}{l}7 \text { (wheelchair aged } \\
33 \text { years) }\end{array}$ & $56 / 42$ & $2.8^{5}$ & c.1076-22T > G & {$[c .1426 C>A ; c .1437+1 G>A]$} & 34 & $f$ \\
\hline $18^{\beta}$ & 12 & limb girdle weakness & 0 & $98 / 90$ & $0.3^{\$}$ & c. $-32-13 T>G$ & c. $307 \mathrm{~T}>\mathrm{G}$ & 12 & f \\
\hline 19 & 12 & limb girdle weakness & 0 & $108 / 105$ & $1.0^{\$}$ & c. $-32-13 \mathrm{~T}>\mathrm{G}$ & c.1143delC & 25 & $\mathrm{~m}$ \\
\hline 20 & 13 & muscle weakness & 3 & $50 / 46$ & $0.3^{\$}$ & c. $2014 C>T$ & c. $1703 \mathrm{~A}>\mathrm{T}$ & 25 & $f$ \\
\hline 21 & 15 & muscle weakness & 0 & $65 / 60$ & $1.1^{\$}$ & c. $-32-13 T>G$ & C. $1441 T>C$ & 17 & $\mathrm{~m}$ \\
\hline $22^{\beta}$ & 16 & muscle weakness & 3 & $69 / 58$ & $1.2^{5}$ & c. $-32-13 \mathrm{~T}>\mathrm{G}$ & c.307T > G & 19 & $f$ \\
\hline \multicolumn{10}{|c|}{ adult } \\
\hline 23 & 12 & $\begin{array}{l}\text { weakness of trunk muscles, } \\
\text { scoliosis }\end{array}$ & 4 & $61 / 36$ & $0.04^{\S}$ & c. $-32-13 T>G$ & c.1799G $>A$ & 48 & $\mathrm{~m}$ \\
\hline
\end{tabular}


Table 1 Clinical, enzymatic and molecular information on 42 German patients with Pompe disease (Continued)

\begin{tabular}{|c|c|c|c|c|c|c|c|c|c|}
\hline 24 & 18 & muscle weakness & 3 & $50 / 25$ & $1.0^{\$}$ & c. $-32-13 \mathrm{~T}>\mathrm{G}$ & c.1143delC & 46 & $\mathrm{~m}$ \\
\hline 25 & 18 & muscle weakness & 2 & $53 / 30$ & $1.2^{\$}$ & c. $-32-13 T>G$ & C.701C $>A$ & 52 & $\mathrm{~m}$ \\
\hline 26 & 20 & limb girdle weakness & 3 & $71 / 46$ & $3.9^{\$}$ & c. $-32-13 T>G$ & $c .877 \mathrm{G}>\mathrm{A}$ & 44 & $f$ \\
\hline $27^{a}$ & 23 & limb girdle weakness & $\begin{array}{l}4 \text { (walking support } \\
\text { aged } 33 \text { years) }\end{array}$ & $76 / 68$ & $0.03^{\S}$ & c. $-32-13 T>G$ & c.1291_1299delCTGCACCAG & 35 & $\mathrm{~m}$ \\
\hline 28 & 27 & limb girdle weakness & $\begin{array}{l}6 \text { (walking support } \\
\text { aged } 51 \text { years) }\end{array}$ & $33 / 26$ & $4.7^{\$}$ & c. $-32-13 T>G$ & c. $1802 C>T$ & 53 & $\mathrm{~m}$ \\
\hline $29^{a}$ & 29 & limb girdle weakness & 0 & $101 / 81$ & $0.09^{\S}$ & c. $-32-13 \mathrm{~T}>\mathrm{G}$ & c.1291_1299delCTGCACCAG & 42 & $f$ \\
\hline 30 & 30 & limb girdle weakness & 3 & $98 / 90$ & $1.2^{\$}$ & c. $-32-13 T>G$ & c.525delT & 47 & $f$ \\
\hline 31 & 30 & limb girdle weakness & 3 & $66 / 25$ & $1.8^{\$}$ & c. $-32-13 \mathrm{~T}>\mathrm{G}$ & $c .2608 C>T$ & 46 & $f$ \\
\hline 32 & 30 & backache & 1 & $?$ & $0.8^{\$}$ & c. $-32-13 T>G$ & c.1005_1006insGG & 70 & $\mathrm{~m}$ \\
\hline 33 & 35 & limb girdle weakness & 3 & $43 / 19$ & $4.1^{\$}$ & c. $-32-13 T>G$ & c.1564C>G & 45 & $m$ \\
\hline 34 & 35 & $\begin{array}{l}\text { limb and shoulder girdle } \\
\text { weakness }\end{array}$ & 1 & $124 / 105$ & $4.9^{5}$ & c. $-32-13 \mathrm{~T}>\mathrm{G}$ & $c .307 \mathrm{~T}>\mathrm{G}$ & 37 & f \\
\hline 35 & 38 & limb girdle weakness & $\begin{array}{l}6 \text { (walking support } \\
\text { aged } 57 \text { years) }\end{array}$ & $33 / 18$ & \# & c. $-32-13 T>G$ & $c .2214 G>A$ & 63 & $f$ \\
\hline 36 & 40 & limb girdle weakness & $\begin{array}{l}6 \text { (walking support } \\
\text { aged } 59 \text { years) }\end{array}$ & $50 / 37$ & $1.1^{\$}$ & c. $-32-13 T>G$ & c.2205_2206insT & 70 & $f$ \\
\hline 37 & 47 & limb girdle myalgia & 3 & $120 / 119$ & $2.8^{\zeta}$ & c. $-32-13 T>G$ & $\begin{array}{l}\text { c.2322_2323insGGTGAGTCT- } \\
\text { GCAAACGGGGAGT }\end{array}$ & 59 & $f$ \\
\hline 38 & 48 & limb girdle weakness & $\begin{array}{l}6 \text { (walking support } \\
\text { aged } 62 \text { years) }\end{array}$ & $87 / 61$ & $0.7^{\$}$ & c. $-32-13 T>G$ & $c .877 \mathrm{G}>\mathrm{A}$ & 62 & $f$ \\
\hline 39 & 56 & $\begin{array}{l}\text { limb girdle weakness, } \\
\text { backache }\end{array}$ & 2 & $120 / 114$ & $1.7^{\$}$ & c. $-32-13 T>G$ & $c .2237 G>A$ & 69 & f \\
\hline 40 & $?$ & $?$ & $?$ & $?$ & $1.5^{5}$ & c. $-32-13 \mathrm{~T}>\mathrm{G}$ & c.1687_1688insCACC & 65 & $f$ \\
\hline \multicolumn{10}{|c|}{ asymptomatic } \\
\hline $41^{\gamma}$ & - & asymptomatic & 0 & 95/98 & $0.4^{5}$ & c. $-32-13 T>G$ & c.525delT & 20 & $f$ \\
\hline \multicolumn{10}{|c|}{ excluded from clinical analysis } \\
\hline 42 & - & - & - & - & $\#$ & c. $-32-13 T>G$ & c.2481+102_2646+31del & 1 & $\mathrm{~m}$ \\
\hline
\end{tabular}

a, $\beta$ siblings

${ }^{\gamma}$ first degree cousins.

GAA activity measured in isolated lymphocytes with 4-methylumbelliferyl-a-D-glucopyranoside as substrate and acarbose (normal range of 9-42 nmole/mg/hr).

GAA activity measured according to a former protocol in isolated lymphocytes with 4-methylumbelliferyl-a-D-glucopyranoside as substrate without acarbose (normal range of 0,19-0,45 nmole/mg/hr). Those enzyme

activities were not included in further analysis.

no own data available. 
Table 2 Disease course in 3 classic infantile patients

\begin{tabular}{|c|c|}
\hline \multicolumn{2}{|l|}{ Patient 1} \\
\hline Age & Disease Course \\
\hline$\leq 0$ & $\begin{array}{l}\text { inconspicuous pregnancy, Cesarean section in the } 38^{\text {th }} \text { week of gestation because of a silent cardiotocogram, birth weight } \\
\text { of } 3.6 \mathrm{~kg} \text {, respiratory distress syndrome that required brief ventilation with face mask postpartum }\end{array}$ \\
\hline 3 days & myocloni and a periodic breathing with decreased blood oxygen saturation \\
\hline 2.5 month & $\begin{array}{l}\text { hypotonia, dystonia, reduction of movements, persistent increase of ASAT, ALAT and CK, diagnosis of hypertrophic } \\
\text { cardiomyopathy }\end{array}$ \\
\hline 5 month & $\begin{array}{l}\text { generalised muscular hypotonia, movement of extremities possible, hypertrophic cardiomyopathy } \\
\text { start of enzyme replacement therapy }\end{array}$ \\
\hline 11 month & first free sitting with arm support \\
\hline 16 month & first rolling, tendency to pull to stand, active crawling, IVSd $7.7 \mathrm{~mm}[2.6-5.6]^{\S}$ \\
\hline 22 month & beginning of four point kneeling and crawling, begins supported standing, IVSd 6.9 mm [2.7 - 5.9] \\
\hline $24 / 12$ years & $\begin{array}{l}\text { sitting without arm support with proper head control, supported standing with reduced force of Mm. quadriceps femoris, } \\
\text { IVSd } 6.6 \mathrm{~mm}[2.7-5.9]\end{array}$ \\
\hline 4 years & $\begin{array}{l}\text { Unclear speech, stands on hand and feet, and sits unsupported, crawling, good arm control but poor head control, and } \\
\text { hypotonic upper body, IVSd } 6.7 \mathrm{~mm}[3.3-6.3]\end{array}$ \\
\hline 5 years & start of invasive ventilation in supine position because of atelectasis, normalized cardiac function with IVSd $6 \mathrm{~mm}[3.3-6.3]$ \\
\hline \multicolumn{2}{|l|}{ Patient 2} \\
\hline Age & Disease Course \\
\hline$\leq 0$ & $\begin{array}{l}\text { normal prenatal development despite of developing a hypertrophic cardiomyopathy, spontaneous delivery in the 37th week } \\
\text { of gestation, birth weight of } 3.1 \mathrm{~kg}\end{array}$ \\
\hline 4 days & start of enzyme replacement therapy, IVSd $6.7 \mathrm{~mm}[2.3-4.9]$ \\
\hline 2 month & head control for 2-3 sec. when pulled up from supine position, IVSd $6.6 \mathrm{~mm}[2,4-5,2]$ \\
\hline 5 month & $\begin{array}{l}\text { normal development, normal force, lifts head actively in prone position, rolling from prone to supine position and back, } \\
\text { IVSd } 5 \mathrm{~mm}[2.5-5.3]\end{array}$ \\
\hline 8 month & normal development, supported standing, crawling, free sitting, normal force, IVSd 6 mm [2.6 - 5.6] \\
\hline 11 month & independent walking and standing \\
\hline 15 month & $\begin{array}{l}\text { normal development, normal force, walking but a bit waddling, discrete Facies hypotonica, proper standing up without } \\
\text { Gower's sign, IVSd } 5 \text { mm [2.6 - 5.8] }\end{array}$ \\
\hline \multicolumn{2}{|l|}{ Patient 3} \\
\hline$\leq 0$ & inconspicuous pregnancy, spontaneous delivery in the 39th week of gestation, birth weight of $3.2 \mathrm{~kg}$ \\
\hline 2 month & weak in breathing and sucking \\
\hline 3 month & $\begin{array}{l}\text { generalised muscular hypotonia with respiratory insufficiency, cyanosis, hypertrophic cardiomyopathy, IVSd } 10 \text { mm [1.4 - 3.8] } \\
\text { start of enzyme replacement therapy }\end{array}$ \\
\hline \multicolumn{2}{|c|}{ data on the further course are not yet available } \\
\hline
\end{tabular}

and enabled a nearly asymptomatic life until the end of the 2 years follow-up period.

\section{Disease manifestations in non-classic patients}

The observation period of the included 37 symptomatic non-classic patients ranges from 1.5 to 70 years with a median of 30 (Quartiles: 18, 47) years. Age at onset is known in 36 of them and spans from birth to the age of 56 years with a median of 14 (Quartiles: 2, 30) years. The first symptoms of these patients are categorised in Figure 1.

In four patients it came to a temporary regression of symptoms in childhood or adolescence before their muscle weakness became progressive. Patient 8 had had an early disease onset with postnatal muscular hypotonia and adynamia in swallowing. Her muscular weakness had improved until she developed a proximal muscle weakness at the age of 8 years, which was rapidly progressive and led to wheelchair dependence at the age of 19 years. Patient 9 also had an early onset disease with delayed motor milestones. He reached standing at one year of age and was able to walk aged 3 years. He did well until the age of 17 years, when he was resilient and active, before muscle weakness progressed. Patient 12 suffered from generalised muscular hypotonia at the age of 2 years. His fitness considerably improved during childhood and has remained stable over the observation period until the age of 20 years. Patient 23 manifested weakness of trunk muscles and scoliosis at the age of 12 years, but his fitness improved till the age of 25 years 


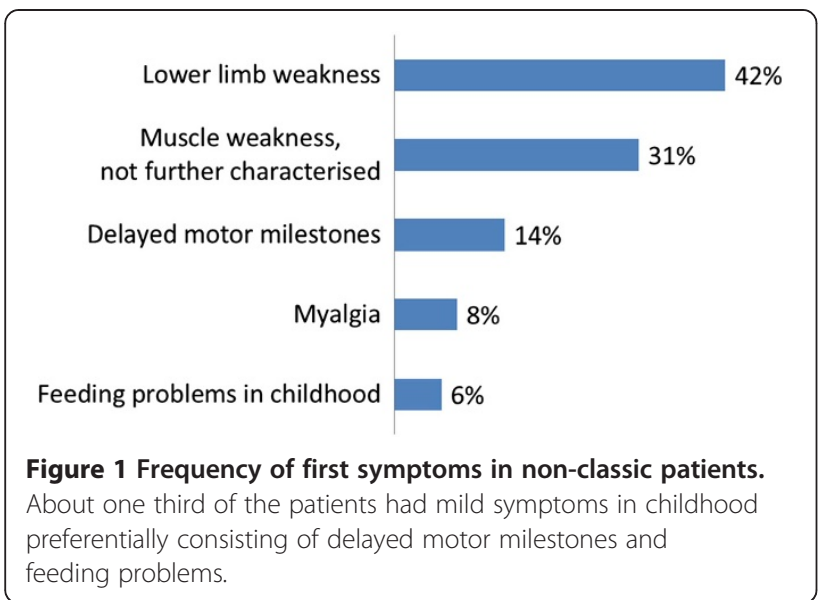

while he was active in sports. Progressive muscle weakness began in his middle twenties and proceeded until the end of the observation period.

Patients were diagnosed between 5 month and 66 years of age with the median age of 22 (Quartiles: 4, 44) years $(\mathrm{n}=36)$. The median diagnostic delay in symptomatic patients was 8 (Quartiles: 2,15) years, ranging from 0 to 34 years $(\mathrm{n}=36)$.

At the end of the observation period 29 of 37 included symptomatic patients $(78 \%)$ were able to walk without any assistance while $5(14 \%)$ needed a supportive device and $3(8 \%)$ a wheelchair. Walking assistance was first used at the median age of 54 (Quartiles: 28, 60) years ranging from 15 to 62 years $(n=6)$. Disease duration until usage of walking assistance had a median of 19 (Quartiles: 12, 21) years ranging from 10 to 24 years $(\mathrm{n}=5)$. The 3 patients using a wheelchair became dependent on it at the age of 17, 19 and 33 years after disease duration of 16, 19 and 24 years. The mobility of each patient graded according to the Walton \& Gardner-Medwin scale is shown in Table 1. The median muscle strength of different muscle groups according to MRC is shown in Figure 2.

Patient 5 needed continuous invasive ventilation since the age of 27 years after disease duration of 26 years. Eight patients (22\%) used non-invasive ventilation while lying. Non-invasive ventilation was started at the median age of 46 (Quartiles: 21, 48) years ranging from 19 to 63 years $(n=9)$ after disease duration of 21 (Quartiles: $17,27)$ years ranging from 11 to 29 years $(n=9)$. FVC in sitting position had a median value of $71 \%$ (Quartiles: $50,92)$ of normal with a range of 28 to $124 \%(n=34)$. It decreased to $60 \%$ (Quartiles: 33, 88) in the supine position with a range of 18 to $119 \%(\mathrm{n}=33)$.

To further explore disease progression we analysed the correlations between clinical parameters and age as well as disease duration that are given in Table 3.

\section{Acid alpha-glucosidase activity and clinical course}

Enzyme activities in lymphocytes of the three classic infantile patients were $1.0,0.3$ and $1.2 \mathrm{nmole} / \mathrm{mg} / \mathrm{hr}$ (Normal range 9-42 nmole/mg/hr). Residual activities of 30 non-classic patients ranged from 0.2 to 4.9 nmole/ $\mathrm{mg} / \mathrm{hr}$ with a median of 1.1 (Quartiles: $0.8,2.0) \mathrm{nmole} /$ $\mathrm{mg} / \mathrm{hr}$. Figure 3 shows the enzyme activities in the different courses of non-classic disease. The WilcoxonMann-Whitney-test revealed significant higher activities in patients with an adult course than in patients with a juvenile course $(\mathrm{p}=0.016)$.

In the group of non-classic patients there was a trend towards later onset of symptoms with higher enzyme activities $\left(r_{s}=0.354, p=0.070\right)$. No correlation was found between the enzyme activity and the current disease severity (i.e. the sum of muscle strength according to the MRC for the different muscle groups and the forced vital capacity).

\section{Serum enzymes}

Serum values of creatine kinase (CK), lactate dehydrogenase (LDH), alanine aminotransferase (ALAT) and aspartate aminotransferase (ASAT) were elevated in nearly all patients. Their distribution is shown in Table 4.

\section{Mutation spectrum}

Mutations were identified in each of the 77 alleles (Table 1). Figure 4 shows their random distribution over the GAA gene, Table 5 their frequency and predicted effect $[9,25,26]$. Of the 33 different variants that we identified, 14 (42\%) had not been reported previously.

\section{Novel mutations}

In total, we identified 14 novel mutations. Six of them lead to a premature stop in protein synthesis (c.1005 1006insGG, c.1143delC, c.1687_1688insCACC, c.2205_ 2206insT, c.2214 G > A and c.2322_2323insGGTGAGTCTGCAAACGGGGAGT). One splice site mutation c. $1437+1$ G $>$ A occurring 'in cis' with c.1426 C > A (p.Leu476Met) was found compound heterozygous with the intronic mutation c.1076-22 T $>$ G, also causing aberrant splicing. Cloning of the transcriptional products into an expression vector system demonstrated that there were no normally spliced products derived from the c. $[1426 \mathrm{C}>\mathrm{A} ; 1437+1 \mathrm{G}>\mathrm{A}]$ allele. The alternatively spliced products derived from the c.1076-22 $\mathrm{T}>\mathrm{G}$ allele had the wild type cytosine at position c.1426. Thus the variants at position c.1426 C > A (p.Leu476Met) and c. $1437+1 \mathrm{G}>\mathrm{A}$ are located on the same allele. In the solely identified splice product of the c. $[1426 \mathrm{C}>\mathrm{A}$; $1437+1$ G $>$ A] allele exon 9 was skipped (r.1327_ $1437 \mathrm{del})$, which results in a protein bearing the in frame deletion p.Asp443_Lys479del. 


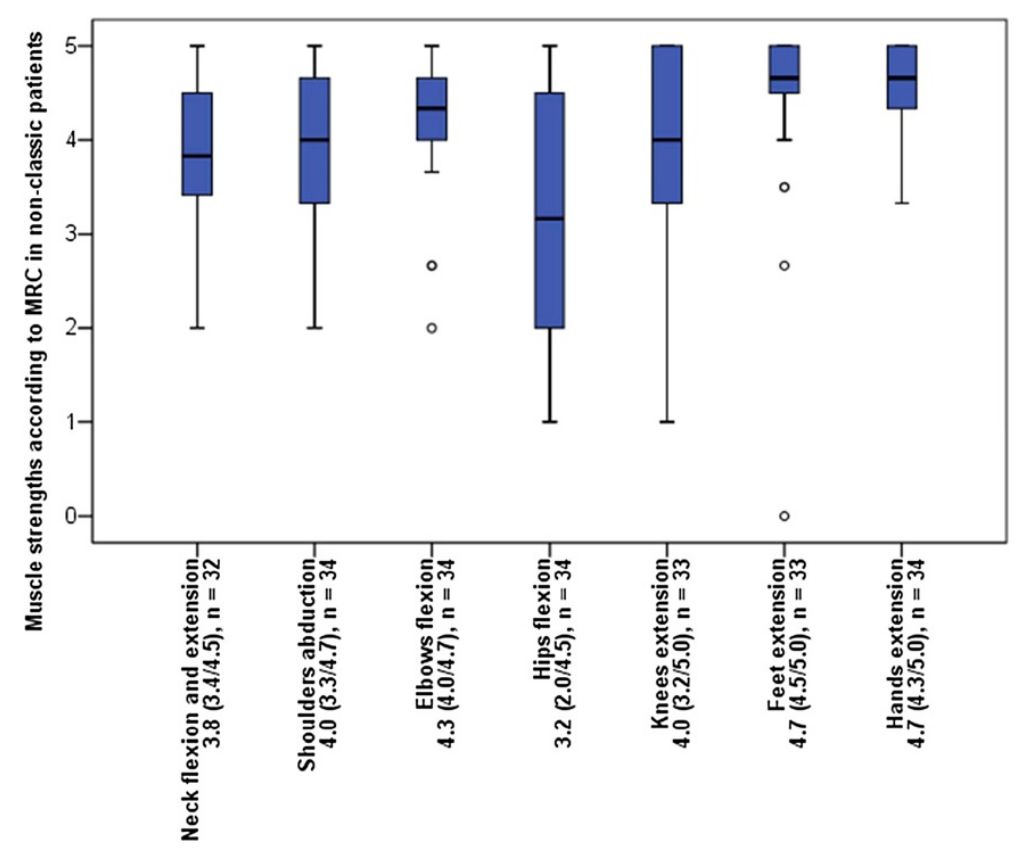

Figure 2 Muscle strength of different muscle groups in non-classic patients according to MRC. The median muscle strength shows a predominant involvement of proximal muscles. The lower limbs are most affected.

The third splice site mutation c.1637-2A $>\mathrm{G}$ also appeared to fully prevent correct splicing. Instead, 5 alternative splice products could be cloned all of which lack the 5'-end of exon 12. Amplification of cDNA with CTG GAG GGT CCC CCC AAC CAC C as reverse primer located in this region did not reveal any products.

Furthermore, five novel missense mutations and one deletion of 9 nucleotides were identified (c.701 C > A (pThr234Lys) c.1703A $>$ T (p.His568Leu), c.1802 C > T (p.Ser601Leu), c.2297A > G (p.Tyr765Cys), c.2738 C > G (p.Pro912Arg) and c.1291_1299delCTGCACCAG (p.Leu431_Gln433del)). These mutations were not encountered among 120 alleles of unaffected persons. The corresponding amino acids are highly conserved among all compared eutheria (Additional file 2).

\section{Genetic variability}

We analysed 34 SNPs located within the sequenced areas and compared their frequencies to those of reference populations (Additional file 3) $[9,25,27]$.
In patients bearing the c.-32-13 $\mathrm{T}>\mathrm{G}$ mutation the variants c.324 C $>\mathrm{T}$ (p.Cys108Cys), c.596 G>A (p. Arg199His), c.668A $>$ G (p.His223Arg), c.1203A > G (p. Gln401Gln), c.1327-18 G>A, c.2040+20 G>A and c.2338A $>$ G (p.Ile780Val) appear considerably more frequent than in reference collectives (Hapmap-CEU, AoD Caucasian). In patients not bearing c.-32-13 $\mathrm{T}>\mathrm{G}$ the frequencies of these polymorphisms are similar to those of the reference collectives.

In the $5^{\prime}$-untranslated region of the GAA gene we identified the novel polymorphism c.-367-157 C > G on 9/52 alleles of the patients bearing the c.-32-13 $\mathrm{T}>\mathrm{G}$ mutation.

\section{Genotype-phenotype correlations}

All three patients with classic infantile Pompe disease had two severe mutations. In the patients with nonclassic disease we analysed the disease manifestation according to the prevalence of the common c.-32-13 $\mathrm{T}>$ G mutation. Patient 16 is homozygous for c.-32-13 T > G as was confirmed by demonstrating heterozygosity of

Table 3 Correlation of clinical parameters with age and disease duration in patients with non-classic disease

\begin{tabular}{llllll}
\hline & \multicolumn{2}{c}{ Correlation with age } & & \multicolumn{2}{c}{ Correlation with disease duration } \\
\cline { 2 - 3 } & Spearman-Rho & Significance & & Spearman-Rho & Significance \\
\hline Total MRC-score & -0.491 & 0.006 & -0.543 & 0.002 \\
\hline Walton \& Gardner-Medwin Scale & 0.451 & 0.005 & 0.481 & 0.003 \\
\hline FVC supine & -0.214 & 0.231 & -0.507 & 0.003 \\
\hline FVC sitting & 0.001 & 0.994 & -0.399 & 0.021 \\
\hline
\end{tabular}




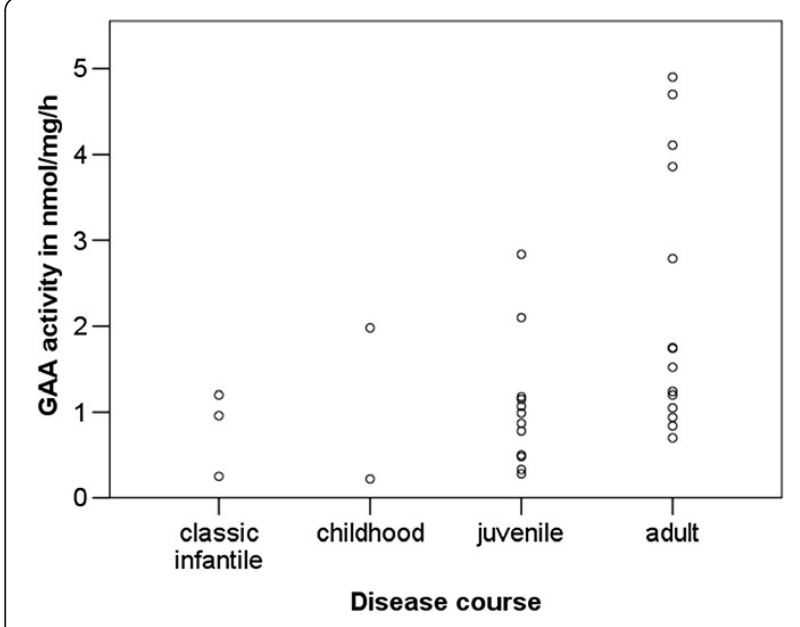

Figure 3 Correlation between disease course and residual acid alpha-glucosidase activity in lymphocytes.

both his parents. He attracted attention at the age of 13 years by a reduced resilience with a slight muscle weakness. In c.-32-13 $\mathrm{T}>\mathrm{G}$ genetic compounds the Log-Rank test showed a later onset compared to patients with other mutations $(\mathrm{p}=0,025)$ (Figure 5$)$. The age at onset of c.-32-13 T>G genetic compounds was 18 (Quartiles: 2, 30) years ranging from 0 to 56 years $(\mathrm{n}=31)$. Four patients bearing two other mutations had first symptoms at the age of $1.5,1.5,9$ and 13 years respectively. In summary the c.-32-13 $\mathrm{T}>\mathrm{G}$ mutation is associated with a later disease manifestation.

\section{Discussion}

\section{Disease manifestations in classic infantile patients}

Until the start of ERT, patient 1 (at 5 month of age) and patient 3 (at 3 month of age) had a characteristic course with hypertrophic cardiomyopathy and respiratory problems resulting from muscular hypotonia developing in the first month of life $[3,28]$. The hypertrophic cardiomyopathy of patient 2 was discovered prenatally and ERT was started on day 4 after birth. This early intervention resulted in normalisation of the left ventricular wall thickness and a near normal development of the

Table 4 Serum enzymes of 2 patients with classic infantile and 29 patients with non-classic disease

\begin{tabular}{lllll}
\hline & CK [U/I] & LDH [U/I] & ALAT [U/I] & ASAT [U/I] \\
\hline Reference values & $30-200$ & $<245$ & $<50$ & $5-35$ \\
\hline Median & 607 & 363 & 94 & 82 \\
\hline Minimum & 148 & 242 & 40 & 25 \\
\hline 25th percentile & 388 & 302 & 62 & 64 \\
\hline 75th percentile & 899 & 476 & 188 & 154 \\
\hline Maximum & 2256 & 1416 & 548 & 532 \\
\hline
\end{tabular}

There were not found significant differences in serum enzymes depending on the different courses of disease. child up to the age of 2 years, in contrasts to the natural course of disease whereby higher motor milestones are not reached. Notably, similar effects have been reached by newborn screening and immediate initiation of ERT in 5 patients with classic infantile Pompe disease from Taiwan [29]. ERT in patient 1, who was already symptomatic at the start of therapy, resulted in a reduction of the left ventricular wall thickness to normal values and delayed, but not prevented, the occurrence of typical symptoms. This confirms previous findings that the outcome of enzyme replacement therapy depends on the clinical status of the patient at start of treatment and underlines the relevance of an early diagnosis followed by an immediate intervention [30].

\section{Disease manifestations in non-classic patients}

There is a broad heterogeneity in the clinical course of non-classic Pompe disease with onset between birth and late adulthood. In our study the median age of onset was considerably younger than in previous studies $[4,13]$. This is explained in part by the fact that we have interpreted any symptom that probably relates to Pompe disease as disease onset while in other studies the beginning of progressive muscle wasting was mostly taken as first symptom. Accordingly the spectrum of first symptoms differs. Though muscle weakness is the most frequent initial symptom, other complaints like delayed achievement of motor milestones or feeding problems in childhood appear rather common $[4,13]$. With regard to the diagnostic delay of 8 years these findings emphasise the necessity of being aware that nonclassic forms of Pompe disease can manifest in the first years of life. Additional sensitive hints can be given by serum values of CK, LDH, ALAT and ASAT that were clearly elevated in nearly all patients. Elevations of LDH, ASAT and ALAT in daily diagnostic routine can point to a muscle disease and should be further investigated by determining the CK even in asymptomatic patients. Since the efficacy of enzyme replacement therapy depends on the clinical state at start of therapy, it is important to diagnose patients before the disease has progressed to muscle wasting [31]. Remarkably, none of our patients initially had respiratory complaints in contrast to other studies wherein approximately one third of the patients had respiratory symptoms before locomotive problems manifested $[5,13]$. This might be explained by a difference in data acquisition, whereby we extracted the first symptoms from the patients' health reports. The absence of subjectively sensed disorders does not exclude the prevalence of a relevant respiratory insufficiency.

Progressive muscle wasting was the salient clinical feature. The characteristic pattern of involvement of different muscle groups described previously could be 


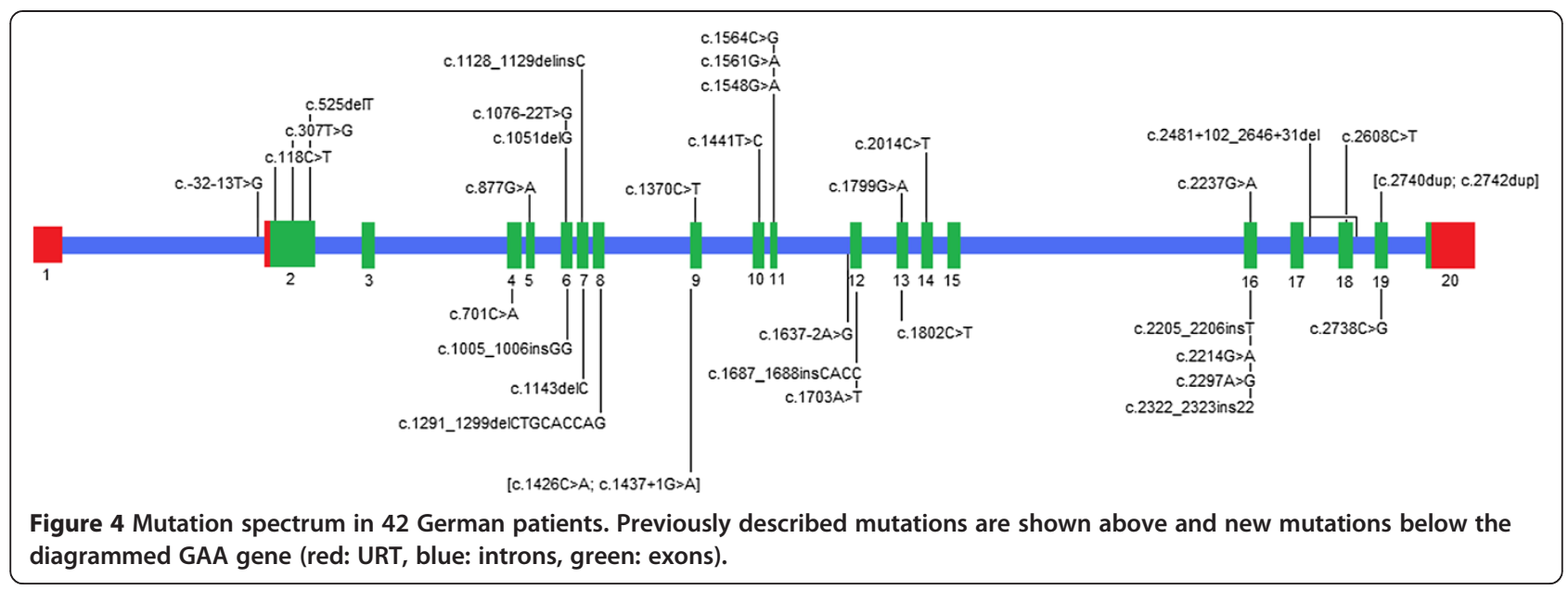

confirmed [13,32]. There is a clear increase of involvement from the distal to the proximal muscles while the lower limbs are more affected than the upper limbs. Reduced strength of skeletal muscles leads to impaired walking and breathing, but the range of functional loss is very broad. Reduction of force and muscle function were correlated with age and disease duration and forced vital capacities were correlated with disease duration showing the progressive course of Pompe disease.

\section{Mutation analysis}

Since molecular defects causing Pompe disease are numerous with most mutations appearing only sporadically, sequencing is the most appropriate method for their analysis $[16,33]$. To prevent the missing of large deletions we analysed both genomic DNA as well as cDNA in large fragments. By this we reached a sensitivity of $100 \%$. Furthermore, we investigated all newly discovered sequence variants for their pathogenic nature in order to exclude false positive identification.

\section{Mutation spectrum}

Our study underlines the enormous heterogeneity at the GAA locus that has come to light in a number of studies that were performed over the past ten years. As much as $73 \%$ (24 out of 33 ) of all mutations that we identified in our present study were only encountered once [9-14,33-35].

The very frequent observation of the c.-32-13 T > G mutation among the German patients studied (34 of the 38 children and adults) corresponds with the previously reported high frequency of this mutation in patients from Central and Southern Europe [10-14]. We also encountered the deletions of exon 18 (c.2481+102 $2646+31$ del) and c.525delT in several patients, but these two mutations seem not as common in the German as in the Dutch population [10-14,34,35]. Furthermore, our studies confirmed that the missense mutations c.307 T $>\mathrm{G}$ and c.877 G>A are probably more frequent in Germany than in other European countries [14,16,35].

\section{Novel mutations}

All the protein truncating mutations that were identified in this study are assumed to be deleterious since their stop codons are located upstream of those that are known to result in a complete loss of enzyme activity [9].

The complex mutation c.[1426 C > A; $1437+1$ G > A] leads to exon 9 skipping. The concurrence of this mutation together with the mild splice site mutation c.1076$22 \mathrm{~T}>\mathrm{G}$ in a patient with onset of symptoms at the age of 9 years and wheelchair dependency at the age of 33 years indicates that c. [1426 C > A; $1437+1 \mathrm{G}>\mathrm{A}$ ] probably leads to complete loss of function [36].

Regarding the mutation c.1637-2A > G the absence of any normally spliced product conforms to the classic infantile course of Pompe disease in patient 2 who is homozygous for this mutation.

The disease causing effect of some of the novel missense mutations and of the 9 base pairs deletion was not directly proven, since no functional studies were carried out. Yet, their absence on 120 alleles of unaffected persons as well as patients together with the conservation of the affected amino acids among the twenty-two eutheria (Additional file 2) makes it very likely that they are disease causing. The substitution c.1802 C > T (p.Ser601Leu) is the third mutation discovered in this codon. Previously, c.1802 C> G (p.Ser601Trp) and c.1802 C > A (pSer601X) were reported as pathogenic sequence variations $[37,38]$. We found the c.2297A $>$ G mutation in a patient with a childhood course of the disease compound heterozygous with the base exchange c. $1561 \mathrm{G}>\mathrm{A}$ that leads to a total loss of enzyme activity [39]. These findings indicate that c.2297A $>$ G allows for a low residual activity. 
Table 5 Frequency and predicted effect of identified mutations

\begin{tabular}{|c|c|c|c|}
\hline Mutation & Effect on cDNA or protein & Predicted severity $[9,25,26]$ & Frequency \\
\hline c.-32-13T>G & impaired splicing of exon 2 & mild & $\begin{array}{l}34 / 73 \text { alleles in non-classic } \\
\text { patients }\end{array}$ \\
\hline C. $118 \mathrm{C}>\mathrm{T}$ & p.Arg40X & severe & $1 / 42$ alleles at risk \\
\hline c.307T>G & p.Cys103Gly & severe & 2/42 alleles at risk \\
\hline c.525delT & p.Glu176fsX45 & severe & $3 / 42$ alleles at risk \\
\hline c.701C $>A$ & p.Thr234Lys & potentially less severe $^{\alpha}$ & $1 / 42$ alleles at risk \\
\hline c. $877 G>A$ & p.Gly293Arg & severe & 2/42 alleles at risk \\
\hline c.1005_1006insGG & p.Ile336GlyfsX56 & severe & $1 / 42$ alleles at risk \\
\hline c.1051delG & p.Val351CysfsX41 & severe & $1 / 42$ alleles at risk \\
\hline c.1076-22T>G & $\begin{array}{l}\text { p.[Asp319_Val358delinsGlySerArgArgTrpProAla; } \\
\text { Gly334_Val358delinsGlySerArgArgTrpProAla] }\end{array}$ & mild & $\begin{array}{l}\text { 1/73 alleles in non-classic } \\
\text { patients }\end{array}$ \\
\hline c.1128_1129delinsC & p.Trp376CysfsX16 & severe & $1 / 42$ alleles at risk \\
\hline c.1143delC & p.Thr381fsX10 & severe & $2 / 42$ alleles at risk \\
\hline c.1291_1299delCTGCACCAG & p.Leu431_Gln433del & unknown & 1/77 alleles \\
\hline c.1370C $>\mathrm{T}$ & p.Pro457Leu & mild & $\begin{array}{l}1 / 73 \text { alleles in non-classic } \\
\text { patients }\end{array}$ \\
\hline c. $[1426 C>A ; 1437+1 G>A]$ & r.1327_1437del p.Asp443_Lys479del & unknown & 1/77 alleles \\
\hline c. $1441 \mathrm{~T}>\mathrm{C}$ & p.Trp481Arg & severe & $1 / 42$ alleles at risk \\
\hline c.1548G $>A$ & p.Trp516X & severe & $1 / 42$ alleles at risk \\
\hline c.1561G >A & p.Glu521Lys & severe & 2/42 alleles at risk \\
\hline c. $1564 C>G$ & p.Pro522Ala & severe & $1 / 42$ alleles at risk \\
\hline c. $1637-2 A>G$ & $\begin{array}{l}\text { r.[1637_1659del; 1637_1682del; 1637_1738del; } \\
\text { 1637_1754del; [1637_1659del, 1755-110_1755-1ins]] } \\
\text { p.[V547GfsX80; G546AfsX16; G546_E579del; } \\
\text { V547RfsX2; V547_R585delinsGGHLCLQPPVLH- } \\
\text { TLQPAQPLRPDRSHRLPOPLPHPRKLLAPSSALLVTG- } \\
\text { FPSPPAPHSPHGVPHHPR] }\end{array}$ & severe & $1 / 42$ alleles at risk \\
\hline c.1687_1688insCACC & p.GIn563ProfsX73 & severe & $1 / 42$ alleles at risk \\
\hline c.1703A $>T$ & p.His568Leu & unknown & $1 / 77$ alleles \\
\hline c. $1799 \mathrm{G}>\mathrm{A}$ & p.Arg600His & severe & $2 / 42$ alleles at risk \\
\hline$c .1802 C>T$ & p.Ser601Leu & potentially less severe ${ }^{\alpha}$ & 1/77 alleles \\
\hline c. $2014 C>T$ & p.Arg672Trp & intermediate & 1/77 alleles \\
\hline c.2205_2206insT & p.Ser736Xfs & severe & $1 / 42$ alleles at risk \\
\hline$c .2214 G>A$ & p.Trp $738 X$ & severe & $2 / / 42$ alleles at risk \\
\hline c. $2237 \mathrm{G}>\mathrm{A}$ & p.Trp746X & severe & $1 / 42$ alleles at risk \\
\hline$c .2297 A>G$ & p.Tyr765Cys & unknown & 1/77 alleles \\
\hline $\begin{array}{l}\text { c.2322_2323insGGTGAGTCT- } \\
\text { GCAAACGGGGAGT }\end{array}$ & p.Leu775GlyfsX70 & severe & $1 / / 42$ alleles at risk \\
\hline c.2481+102_2646+31del & p.Gly828_Asn882del & severe & 4//42 alleles at risk \\
\hline c. $2608 C>T$ & p.Arg870X & severe & $1 / / 42$ alleles at risk \\
\hline c.2738C $>G$ & p.Pro912Arg & unknown & 1/77 alleles \\
\hline c.[2740dup; 2742dup] & p.Gln914fsX30 & severe & $1 / / 42$ alleles at risk \\
\hline
\end{tabular}

${ }^{a}$ unpublished data, that will be included in the upcoming update of the Pompe disease mutation database novel mutations in bold italics.

Nevertheless the effect of novel mutations should be assessed by functional studies. This would provide the highest insight in the functional effects of the sequence variations as well as the best basis for investigating genotype-phenotype correlation.
Genetic variability

The comparison of the frequencies of 34 polymorphisms with reference populations revealed an association of the mutation c.-32-13 $\mathrm{T}>\mathrm{G}$ with the haplotype [c.324 T, c.596A, c.668 G, c.1203 G, c.1327-18A, c. $2040+20$ A, 


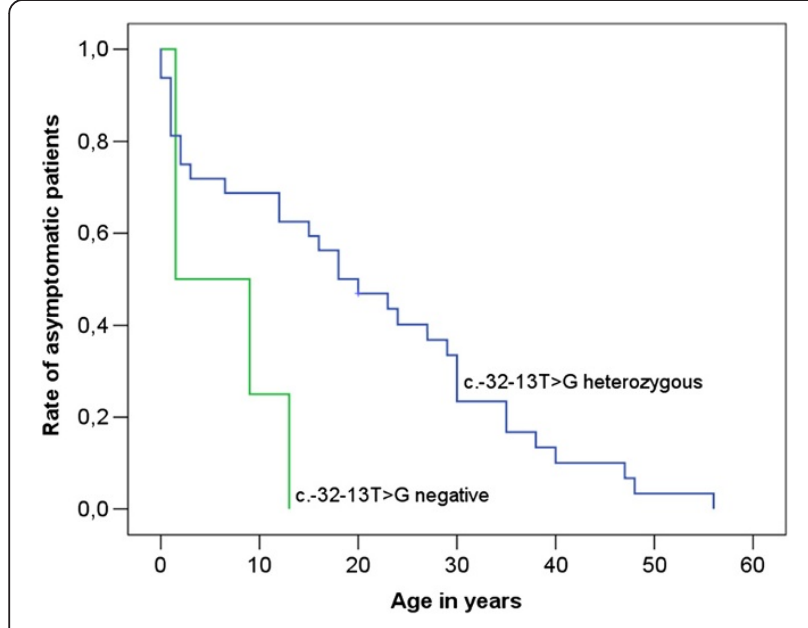

Figure 5 Kaplan-Meier function of age at disease onset depending on the prevalence of the common mutation c.-32$13 \mathrm{~T}>\mathrm{G}$.

c.2338G]. Since in addition the changes c.271 G>A, c.1726 G>A, c.2065 G>A, c.2446 G>A and c.2780 C $>\mathrm{T}$ rarely appear in this cohort the common mutation seems to be associated with the haplotype DHRGEVVT (c.271 G, c.596A, с.668 G, c.1726 G, c.2065 G, c.2338 G, c.2446 G, c.2780 C) in the German population. This association is in line with previous findings in the European population and corroborates the hypothesis of a founder effect [18].

\section{Genotype-phenotype correlations}

The primary effect of residual enzyme activity on the clinical course of Pompe disease can be confirmed $[2,3,10,16,17,40]$. All our classic infantile patients had virtually no enzyme activity due to two severe mutations. Residual activities in non-classic patients correlated with a later age of onset and slower disease progression. All subgroups harboured patients with very low activities. Yet, the highest values were found among the patients with an adult course of the disease. Thus, high residual activities protect against a severe course of disease. Current disease severity did not correlate with enzyme activity although proof of this correlation is difficult to show in such small cohorts with a broad range of current age.

As in previous studies, the most common c.-32-13 $\mathrm{T}>$ $\mathrm{G}$ mutation is associated with a milder course although there is a broad variability in the decline of locomotive and respiratory function $[4,11,13,18]$. This is underlined by the discovery of a c.-32-13 T $>$ G homozygous patient. Since homozygous patients were only sporadically reported it can be assumed that the homozygous state of c.-32-13 $\mathrm{T}>\mathrm{G}$ usually is none-penetrating $[13,41,42]$.

Phenotypic variability points to disease modifying factors that obtain relevance when the underlying pathogenic mutations allow for appreciable residual activity [18] The broad range of enzyme activities in c.-32-13 T $>$ G compound heterozygous patients that cannot be described to the nature of the mutations on the second allele speaks for factors modulating the expression of the GAA gene, alternative splicing or the maturation of the translational products $[43,44]$. Variation can also be envisaged to develop on the basis of qualitative and quantitative differences in the autophagy pathway that influence the lysosomal glycogen deposition [45].

The fact that three of four patients who had a temporal regression of symptoms where quite active might indicate that muscle training can ameliorate the course of disease [46]. Muscle regeneration decreases with age, but is enhanced by training and proper nutrition, especially in young people $[47,48]$. It is certainly worthwhile to further elucidate the regulation of muscle plasticity and regeneration in future studies.

\section{Conclusions}

This study is one of the largest single-centre studies regarding phenotypes as well as genotypes in Pompe disease. The disease course is dominated by progressive locomotive and respiratory impairment in all patients and and hypertrophic cardiomyopathy in patients with classic infantile disease. The clinical spectrum strongly correlates with residual acid alpha-glucosidase activity. Residual activity of this enzyme is primarily determined by the severity of the pathogenic mutations on both GAA alleles and likely controlled by yet unknown modifying factors.

\section{Additional files}

\section{Additional file 1: Protocol of mutation analysis. \\ Additional file 2: Alignment of protein sequences surrounding missense mutations with orthologous enzymes of different eutheria.}

Additional file 3: Allele frequencies of polymorphisms in comparison with reference populations.

\section{Competing interests}

Research was supported by Genzyme Corporation. R Hartung is a member of the European Pompe Registry Board and received compensation from Genzyme Corporation for participation in meetings, AJJ Reuser received consulting honorarium from Genzyme Corporation, M. Beck and E. Mengel received consulting honorarium, payment for lectures and meeting expenses from Genzyme Corporation, S. Gökce received payment for lectures from Genzyme Corporation.

\section{Acknowledgements}

We would like to thank all patients and their families for participating this study, M. Berres (Institute of Medical Biostatistics, Epidemiology and Informatics, University Medical Center, Mainz, Germany) for statistic counselling, as well as our study nurses D. Böke-König, A. Mattes, A. Sieber and $P$. Kleinhans. This study was performed in the broader context of the doctoral thesis work of A. Herzog, and parts of the text are contained in his thesis. Novel mutations will be included in an upcoming update of the Pompe disease mutation database. Research was supported by the European Union $7^{\text {th }}$ Framework Programme 'EUCLYD- A European Consortium for 
Lysosomal Storage Diseases' [health F2/2008 grant agreement 201678 to MB and KEM].

\section{Author details \\ ${ }^{1}$ Center for Pediatric and Adolescent Medicine, University Medical Center, Langenbeckstraße 1, 55131, Mainz, Germany. ${ }^{2}$ Department of Clinical Genetics, Erasmus MC University Medical Center, Dr Molewaterplein 50, 3015GE, Rotterdam, The Netherlands. ${ }^{3}$ Institute of Human Genetics, University of Heidelberg, Im Neuenheimer Feld 366, 69120, Heidelberg, Germany.}

\section{Authors' contributions}

$\mathrm{AH}$ performed mutation analysis, statistical analysis and wrote the manuscript, RH collected clinical data and designed the study. Dr AJJR reviewed the manuscript. Dr PH performed mutation analysis. Dr HR collected clinical data and reviewed the manuscript. Dr NK collected clinical data, SG collected clinical data. Prof. Dr. JP designed the study and reviewed the manuscript. Prof Dr CK performed cardiac evaluation. Dr. CL collected clinical data. Prof Dr MB designed the study and performed biochemical assays. Dr EM designed the study, performed biochemical assays, collected clinical data and reviewed the manuscript. All authors read, edited and approved the final version of the manuscript.

Received: 31 January 2012 Accepted: 7 June 2012

Published: 7 June 2012

\section{References}

1. Hirschhorn R, Reuser AJ: Glycogen storage disease type II. In Acid alphaGlucosidase (acid maltase) deficiency, The metabolic \& molecular bases of inherited disease. 8th edition. Edited by Scriver CR, Beaudet AL, Sly WS, Valle D. New York: McGraw - Hill; 2001. www.ommbid.com.

2. van den Hout HMP, Hop W, Van Diggelen OP, Smeitink JAM, Smit GPA, PollThe BT, Bakker HD, Loonen MCB, De Klerk JBC, Reuser AJJ, van der Ploeg AT: The natural course of infantile Pompe's disease: 20 original cases compared with 133 cases from the literature. Pediatrics 2003, 112:332-340.

3. Kishnani PS, Hwu W, Mandel H, Nicolino M, Yong F, Corzo D: A retrospective, multinational, multicenter study on the natural history of infantile-onset Pompe disease. J Pediatr 2006, 148:671-676.

4. Hagemans ML, Winkel LP, van Doorn PA, Hop WJ, Loonen MC, Reuser AJ, van der Ploeg AT: Clinical manifestation and natural course of late-onset Pompe's disease in 54 Dutch patients. Brain 2005, 128:671-677.

5. Mellies U, Lofaso F: Pompe disease: a neuromuscular disease with respiratory muscle involvement. Respir Med 2009, 103:477-484.

6. Kuo WL, Hirschhorn R, Huie ML, Hirschhorn K: Localization and ordering of acid alpha-glucosidase (GAA) and thymidine kinase (TK1) by fluorescence in situ hybridization. Hum Genet 1996, 97:404-406.

7. Hoefsloot LH, Hoogeveen-Westerveld M, Reuser AJ, Oostra BA: Characterization of the human lysosomal alpha-glucosidase gene. Biochem J 1990, 272:493-497.

8. Hoefsloot LH, Hoogeveen-Westerveld M, Kroos MA, van Beeumen J, Reuser AJ, Oostra BA: Primary structure and processing of lysosomal alphaglucosidase; homology with the intestinal sucrase-isomaltase complex. EMBO J 1988, 7:1697-1704.

9. The Pompe disease mutation database: http://www.pompecenter.nl/en/? Molecular_aspects:Mutations, accessed 27 Feb 2010.

10. Kroos MA, van der Kraan M, van Diggelen OP, Kleijer WJ, Reuser AJ, van den Boogaard MJ, Ausems MG, van Ploos Amstel HK, Poenaru L, Nicolino M: Glycogen storage disease type II: frequency of three common mutant alleles and their associated clinical phenotypes studied in 121 patients. J Med Genet 1995, 32:836-837.

11. Montalvo AL, Bembi B, Donnarumma M, Filocamo M, Parenti G, Rossi M, Merlini L, Buratti E, de Filippi P, Dardis A, Stroppiano M, Ciana G, Pittis MG: Mutation profile of the GAA gene in 40 Italian patients with late onset glycogen storage disease type II. Hum Mutat 2006, 27:999-1006.

12. Gort L, Coll MJ, Chabas A: Glycogen storage disease type II in Spanish patients: high frequency of c.1076-1GC mutation. Mol Genet Metab 2007, 92:183-187

13. Laforet P, Nicolino M, Eymard PB, Puech JP, Caillaud C, Poenaru L, Fardeau $M$ : Juvenile and adult-onset acid maltase deficiency in France: genotypephenotype correlation. Neurology 2000, 55:1122-1128.
14. Joshi PR, Gläser D, Schmidt S, Vorgerd M, Winterholler M, Eger K, Zierz S, Deschauer M: Molecular diagnosis of German patients with late-onset glycogen storage disease type II. 2008, doi:10.1007/s10545-008-0820-2. accessed 20 Nov 2008.

15. Raben N, Nichols RC, Martiniuk F, Plotz PH: A model of mRNA splicing in adult lysosomal storage disease (glycogenosis type II). Hum Mol Genet 1996, 5:995-1000.

16. Hermans MM, van Leenen $D$, Kroos MA, Beesley CE, van der Ploeg AT, Sakuraba H, Wevers R, Kleijer W, Michelakakis H, Kirk EP, Fletcher J, Bosshard $\mathrm{N}$, Basel-Vanagaite L, Besley G, Reuser AJ: Twenty-two novel mutations in the lysosomal alpha-glucosidase gene (GAA) underscore the genotypephenotype correlation in glycogen storage disease type II. Hum Mutat 2004, 23:47-56.

17. Reuser AJ, Kroos M, Willemsen R, Swallow D, Tager JM, Galjaard H: Clinical diversity in glycogenosis type II. Biosynthesis and in situ localization of acid alpha-glucosidase in mutant fibroblasts. J. Clin. Invest 1987, 79:1689-1699.

18. Kroos MA, Pomponio RJ, Hagemans ML, Keulemans JLM, Phipps M, DeRiso M, Palmer RE, Ausems MGEM, van der Beek NAME, van Diggelen OP, Halley DJJ, van der Ploeg AT, Reuser AJJ: Broad spectrum of Pompe disease in patients with the same c.-32-13T-G haplotype. Neurology 2007, 68:110-115.

19. Kampmann C, Wiethoff CM, Wenzel A, Stolz G, Betancor M, Wippermann CF, Huth RG, Habermehl P, Knuf M, Emschermann T, Stopfkuchen H: Normal values of $\mathrm{M}$ mode echocardiographic measurements of more than 2000 healthy infants and children in central Europe. Heart 2000, 83:667-672

20. Falk RE, Casas KA: Chromosome 2q37 deletion: clinical and molecular aspects. Am J Med Genet Part C Semin Med Genet 2007, 145C:357-371.

21. Jack RM, Gordon C, Scott CR, Kishnani PS, Bali D: The use of acarbose inhibition in the measurement of acid alpha-glucosidase activity in blood lymphocytes for the diagnosis of Pompe disease. Genet Med 2006, 8:307-312.

22. Okumiya T, Keulemans JLM, Kroos MA, van der Beek NME, Boer MA, Takeuchi H, van Diggelen OP, Reuser AJJ: A new diagnostic assay for glycogen storage disease type II in mixed leukocytes. Mol Genet Metab 2006, 88:22-28.

23. Hermans MM, van Leenen D, Kroos MA, Reuser AJ: Mutation detection in glycogen storage-disease type II by RT-PCR and automated sequencing Biochem Biophys Res Commun 1997, 241:414-418.

24. den Dunnen JT, Antonarakis SE: Mutation nomenclature extensions and suggestions to describe complex mutations: a discussion. Hum Mutat 2000, 15:7-12.

25. NCBI: SNP's: 2009. http://www.ncbi.nlm.nih.gov/SNP/snp_ref.cgi?showRare= on\&chooseRs=all\&locusld=2548\&mrna=NM_000152.3\&ctg=NT_024871.11\& prot=NP_000143.2\&orien=forward\&refresh=refresh, accessed.

26. Kroos M, Pomponio RJ, van Vliet L, Palmer RE, Phipps M, van der Helm R, Halley D, Reuser A: Update of the Pompe disease mutation database with 107 sequence variants and a format for severity rating. Hum Mutat 2008, 29:E13-E26.

27. Broad Institute: HapMap Data Rel 27 Phasell+III, Feb09, on NCBI B36 assembly, dbSNP b126: chr17:75689950.75708273.: ; http://www.hapmap.org/cgi-perl/ gbrowse/hapmap27_B36/, accessed 7 May 2009.

28. van den Hout JMP, Kamphoven JHJ, Winkel LPF, Arts WFM, de Klerk JBC, Loonen MCB, Vulto AG, Cromme-Dijkhuis A, Weisglas-Kuperus N, Hop W, van Hirtum $H$, van Diggelen OP, Boer M, Kroos MA, van Doorn PA, van der Voort E, Sibbles B, van Corven EJJM, Brakenhoff JPJ, van Hove J, Smeitink JAM, de Jong G, Reuser AJJ, van der Ploeg AT: Long-term intravenous treatment of Pompe disease with recombinant human alphaglucosidase from milk. Pediatrics 2004, 113:e448-e457.

29. Chien Y, Lee N, Thurberg BL, Chiang S, Zhang XK, Keutzer J, Huang A, Wu M, Huang P, Tsai F, Chen Y, Hwu W: Pompe disease in infants: improving the prognosis by newborn screening and early treatment. Pediatrics 2009, 124:e1116-e1125.

30. Kishnani PS, Corzo D, Leslie ND, Gruskin D, van der Ploeg A, Clancy JP, Parini R, Morin G, Beck M, Bauer MS, Jokic M, Tsai C, Tsai BWH, Morgan C, O'meara T, Richards S, Tsao EC, Mandel H: Early Treatment with Alglucosidase Alfa Prolongs Long Term Survival of Infants with Pompe Disease. Pediatr Res 2009, 66:329-335.

31. van der Ploeg AT, Clemens PR, Corzo D, Escolar DM, Florence J, Groeneveld GJ, Herson S, Kishnani PS, Laforet P, Lake SL, Lange DJ, Leshner RT, Mayhew JE, Morgan C, Nozaki K, Park DJ, Pestronk A, Rosenbloom B, Skrinar A, van Capelle Cl, van der Beek NA, Wasserstein M, Zivkovic SA: A randomized 
study of alglucosidase alfa in late-onset Pompe's disease. N Engl J Med 2010, 362:1396-1406.

32. Engel AG: Acid maltase deficiency in adults: studies in four cases of a syndrome which may mimic muscular dystrophy or other myopathies. Brain 1970, 93:599-616.

33. McCready ME, Carson NL, Chakraborty P, Clarke JT, Callahan JW, Skomorowski MA, Chan AK, Bamforth F, Casey R, Rupar CA, Geraghty MT: Development of a clinical assay for detection of GAA mutations and characterization of the GAA mutation spectrum in a Canadian cohort of individuals with glycogen storage disease, type II. Mol Genet Metab 2007. 92:325-335.

34. Hirschhorn R, Huie ML: Frequency of mutations for glycogen storage disease type II in different populations: the delta525T and deltaexon 18 mutations are not generally "common" in white populations. J Med Genet 1999, 36:85-86.

35. Pittis MG, Donnarumma M, Montalvo AL, Dominissini S, Kroos M, Rosano C, Stroppiano M, Bianco MG, Donati MA, Parenti G, D'Amico A, Ciana G, Di Rocco M, Reuser A, Bembi B, Filocamo M: Molecular and functional characterization of eight novel GAA mutations in Italian infants with Pompe disease. Hum Mutat 2008, 29:E27-E36.

36. Vorgerd M, Burwinkel B, Reichmann H, Malin JP, Kilimann MW: Adult-onset glycogen storage disease type II: phenotypic and allelic heterogeneity in German patients. Neurogenetics 1998, 1:205-211.

37. Palmer RE, Amartino HM, Niizawa G, Blanco M, Pomponio RJ, Chamoles NA: Pompe disease (glycogen storage disease type II) in Argentineans: clinical manifestations and identification of 9 novel mutations. Neuromuscul Disord 2007, 17:16-22.

38. Manwaring V, Prunty H, Bainbridge K, Burke D, Finnegan N, Franses R, Lam A, Vellodi A, Heales S: Urine analysis of glucose tetrasaccharide by HPLC; a useful marker for the investigation of patients with Pompe and other glycogen storage diseases. J Inherit Metab Dis 2012, 35:311-316.

39. Hermans MM, de Graaff E, Kroos MA, Wisselaar HA, Oostra BA, Reuser AJ: Identification of a point mutation in the human lysosomal alphaglucosidase gene causing infantile glycogenosis type II. Biochem Biophys Res Commun 1991, 179:919-926.

40. Umapathysivam K, Hopwood JJ, Meikle PJ: Correlation of acid alphaglucosidase and glycogen content in skin fibroblasts with age of onset in Pompe disease. Clin Chim Acta 2005, 361:191-198.

41. Sharma MC, Schultze C, von Moers A, Stoltenburg-Didinger G, Shin YS, Podskarbi T, Isenhardt K, Tews DS, Goebel HH: Delayed or late-onset type II glycogenosis with globular inclusions. Acta Neuropathol 2005, 110:151-157.

42. Müller-Felber W, Horvath R, Gempel K, Podskarbi T, Shin Y, Pongratz D, Walter MC, Baethmann M, Schlotter-Weigel B, Lochmuller H, Schoser B: Late onset Pompe disease: clinical and neurophysiological spectrum of 38 patients including long-term follow-up in 18 patients. Neuromuscul Disord 2007, 17:698-706.

43. Cooper TA, Wan L, Dreyfuss G: RNA and disease. Cell 2009, 136:777-793.

44. Yan B, Raben N, Plotz P: The human acid alpha-glucosidase gene is a novel target of the Notch-1/Hes-1 signaling pathway. J Biol Chem 2002, 277:29760-29764

45. Raben N, Hill V, Shea L, Takikita S, Baum R, Mizushima N, Ralston E, Plotz P: Suppression of autophagy in skeletal muscle uncovers the accumulation of ubiquitinated proteins and their potential role in muscle damage in Pompe disease. Hum Mol Genet 2008, 17:3897-3908.

46. Slonim AE, Bulone L, Goldberg T, Minikes J, Slonim E, Galanko J, Martiniuk F: Modification of the natural history of adult-onset acid maltase deficiency by nutrition and exercise therapy. Muscle Nerve 2007, 35:70-77.

47. Ambrosio F, Kadi F, Lexell J, Fitzgerald GK, Boninger ML, Huard J: The effect of muscle loading on skeletal muscle regenerative potential: an update of current research findings relating to aging and neuromuscular pathology. Am J Phys Med Rehab / Assoc Acad Physiatr 2009, 88:145-155.

48. Harridge SDR: Plasticity of human skeletal muscle: gene expression to in vivo function. Exp Physiol 2007, 92:783-797.

doi:10.1186/1750-1172-7-35

Cite this article as: Herzog et al:: A cross-sectional single-centre study on the spectrum of Pompe disease, German patients: molecular analysis of the GAA gene, manifestation and genotype-phenotype correlations. Orphanet Journal of Rare Diseases 2012 7:35.

\section{Submit your next manuscript to BioMed Central and take full advantage of:}

- Convenient online submission

- Thorough peer review

- No space constraints or color figure charges

- Immediate publication on acceptance

- Inclusion in PubMed, CAS, Scopus and Google Scholar

- Research which is freely available for redistribution 